CORRESPONDENCE

\title{
Discussion of 'Structure and eruptive mechanisms at Surtsey Volcano, Iceland' by J. G. Moore
}

SIRS - Measurements taken from photographs of Surtseyan explosions, and basaltic tephra recovered from a borehole into Surtsey, are the bases of models of the structure and eruption mechanisms of Surtsey Volcano recently published in this journal (Moore, 1985). Measurements of the basal diameters of explosion columns range up to $250 \mathrm{~m}$ and the large diameters were interpreted as indicating explosions that quarried downwards more than $300 \mathrm{~m}$ into the volcano's substrate. It was suggested that this downward quarrying was a possible mechanism in the formation of some diatremes. Appraisal of the diameter measurements shows that there is doubt as to their validity and that the large dimensions are exaggerated. Even if the data were correct, they may not have the significance ascribed to them, particularly because the basal diameters of the columns do not directly reflect conduit dimensions. Also, evidence for aspects of the proposed volcano structure and eruption mechanisms is lacking or, arguably, should be interpreted differently. In particular, the proposed early development of a thick pillow-lava pile, and the likelihood of there having been an open vent extending to a considerable depth below sea level, are questioned. It is concluded that there is no certain evidence from Surtsey to support the proposed downward quarrying in the formation of diatremes.

Surtsey is an island, off the south coast of Iceland, that was formed during the period 1963-7 by basaltic eruptions at the two main vents of Surtsey Volcano. Satellite vents constructed the ephemeral islands Syrtlingur and Jolnir and a submarine pile called Surtla. Kokelaar \& Durant (1983) gave evidence of processes involved in the submarine growth of Surtla; it seems reasonable to infer similar processes in the submarine growth of Surtsey. Kokelaar (1983) proposed that Surtseyan explosions, of both tephra finger and continuous uprush types (Thorarinsson et al. 1964), result mainly from mixing, within the volcanic pile, of hot, fluid magma with a highly mobile slurry of tephra, water, and steam. Moore's models of the volcano structure and eruption mechanisms are dissimilar to those of Kokelaar (1983).

Measurements of 'radial distance from vent centre to basal edge of explosion column' in Moore's table 1 are of particular importance in his models. Moore states: 'The great vigour and tall, cylindrical nature of the continuous uprushing columns suggest that the depth to the base of the explosions is probably much greater than the diameter of the explosion column...' Moore ascribes most importance to the uprush columns, claims that their basal diameters ranged up to $250 \mathrm{~m}$, and infers (fig. 9) that the explosions quarried downwards more than $300 \mathrm{~m}$ into the volcano's substrate. It is this downward quarrying that is invoked as a possible origin of some diatremes.

Figure 1 shows tracings of 9 of the 12 photographs from which Moore derived his radial distance data. (These include the photographs showing the large measured dimensions.) Superimposed on the tracings and centred above the associated vents are Moore's basal diameters of the explosion columns (twice the 'radial distance from vent centre to basal edge of explosion column' given in his table 1). The superimposed dimensions are best approximations, because the scales, which are given in or inferred from the original paper containing the photographs, are commonly approximate and difficult to use. Nevertheless, possible errors do not significantly alter the general points made here.

Figure 1(a): The photograph was taken shortly after emergence of the island, when eruptions occurred along a fissure. The view is at right-angles to the fissure such that dimensions given are lengths along the fissure and description as 'radial distance from vent centre' in this case is misleading. Moore interprets the explosions as being of continuous uprush type, but Thorarinsson et al. (1964, pp. $438,439)$ refer clearly to explosions occurring frequently and at varying intervals, and the picture is used by them to illustrate discrete, tephra finger (cypressoid) jets.

Figure 1(b): Billowing, convective rise of tephra-laden steam (condensed) is shown, and is associated with a phase of continuous uprush activity. (Tephra-free steam rises from an adjacent, 'inactive' vent.) The column is displaced relative to the vent and broadens rapidly within the first $100 \mathrm{~m}$ above it. The base of the column is obscured. The diameter given is wider than the lowest part of the column, and is almost certainly greater than the diameter of the area bounded by the foot (sea level) of the inner cone-slope (see Thorarinsson et al. 1964, fig. 6).

Figure 1(c): A discrete asymmetric tephra finger (cock's tail) explosion is shown, its form indicating a distinct vent locus and basal diameter probably no more than about one-half to two-thirds of the diameter given.

Figure 1(d): A small, roughly symmetrical tephra finger (cock's tail) explosion is seen amidst copious condensed steam that completely obscures the vent. As far as can be determined, the given basal dimension is the maximum admissible from backward projection of visible trajectories (fingers).

Figure 1(e): The picture shows a continuous uprush that followed shortly after the discrete jet activity of Figure 1 (d). Scale, inferred from jet height in relation to tuff cone diameter in Figure 1(d), is only approximate. The diameter given by Moore is approximately that of the area defined by the base of the inner cone-slope, but in the photograph the basal part of the column is very indistinct; the gas thrust region is not visible. Much of the tephra-laden condensed steam around the column base could be descending.

Figure $1(\mathrm{f})$ : This view is distant and the eruption is greatly obscured. Scale is difficult to apply, the nature of the explosivity is difficult to determine, and fallout is difficult to distinguish from the explosion column.

Figure $1(\mathrm{~g})$ : The picture shows a tephra finger (cock's tail) explosion at Jolnir. Scale is derived from the length of the island. The given basal diameter is a reasonable maximum.

Figure 1(h): A typical cock's tail explosion is shown, and it is impossible to define the base of the 'column'. The basal diameter given seems much wider than can be inferred by tracing visible trajectories back to the centre of the explosion.

Figure 1(i): The column is due to continuous uprush at Jolnir; the column base is obscured. The given basal diameter is about three times wider than the diameter of the crater floor measured 2 and 30 days earlier, and much wider than the floor after the eruption (see Thorarinsson, 1968, fig. 

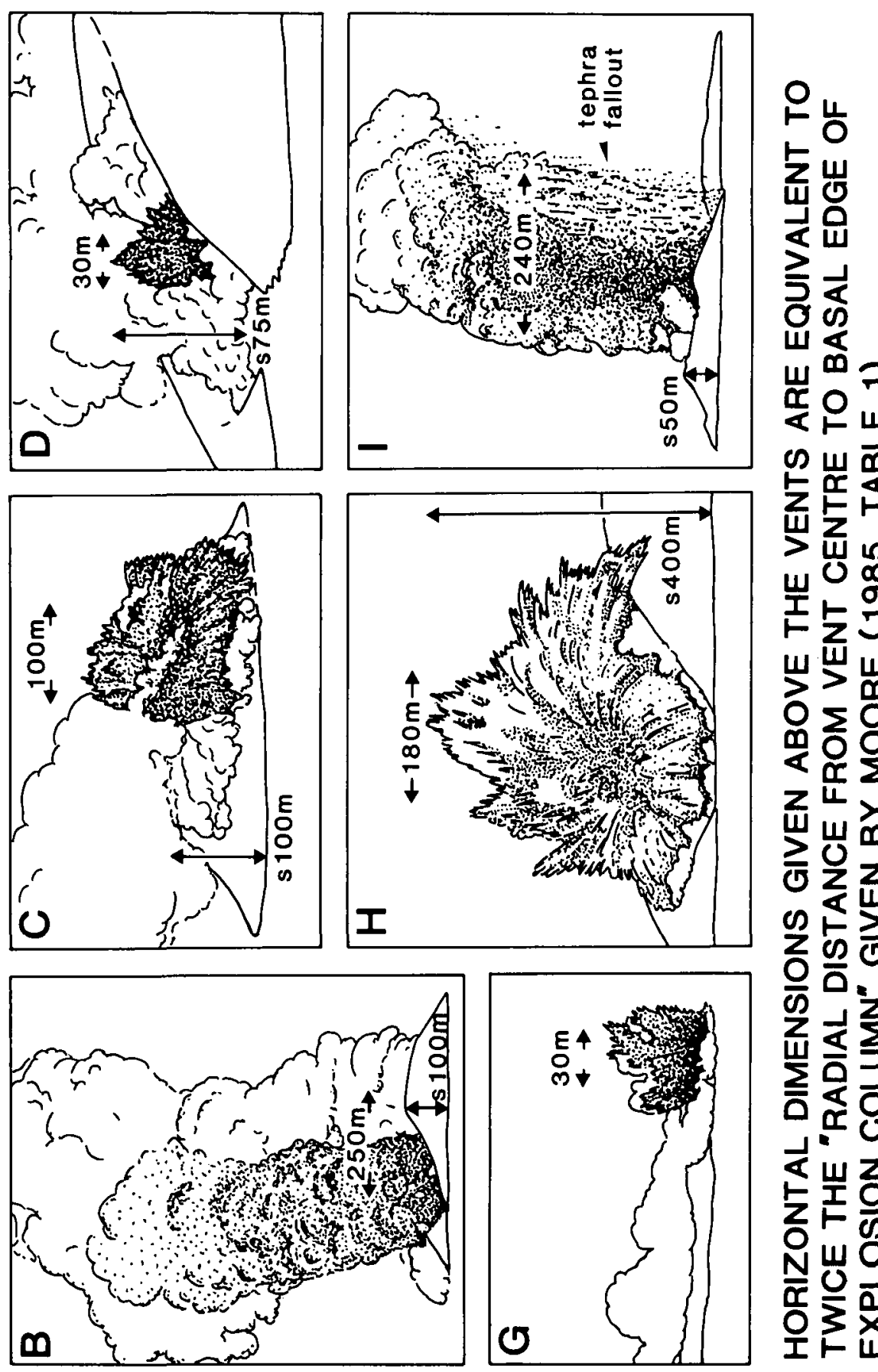

点崖市岁

ํㅗำ

ய岕占

F之E 㟧 $\sum$ 宁

шщ山 㟧

Oํํㄹ

m

我 品

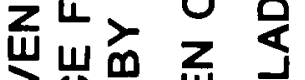

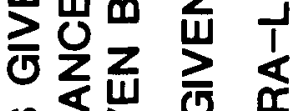

の市市心

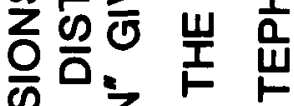

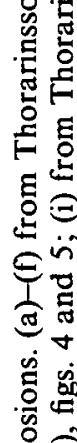

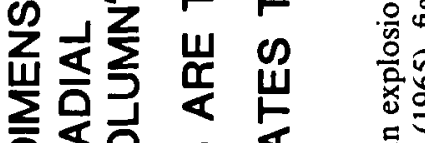

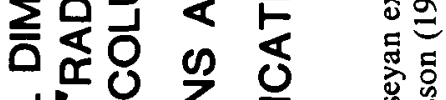

选出

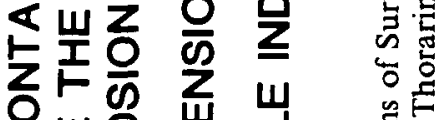

뻥 एँ

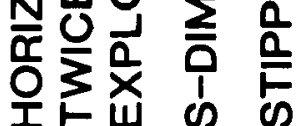

起
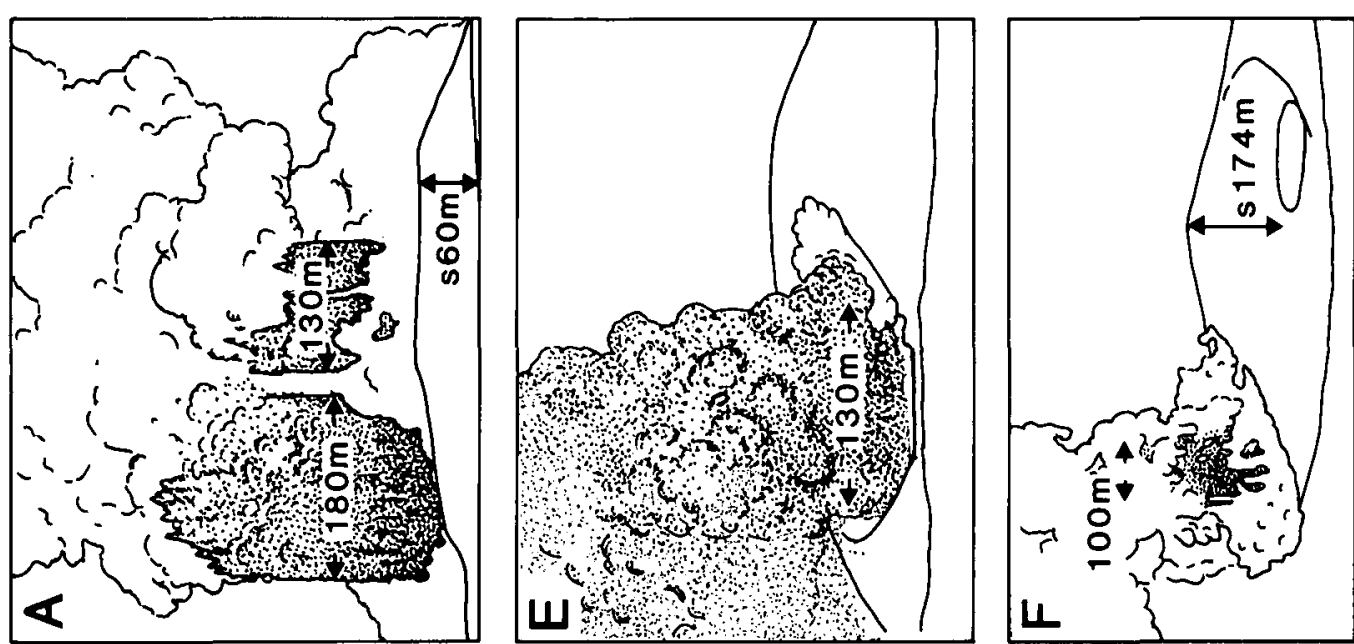

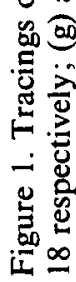


2 and plate $2 \mathrm{~b}$ ); it includes a broad sheath of tephra fallout, which is not explosion column. The actual basal diameter is probably less than $100 \mathrm{~m}$.

The main conclusion to be drawn from this appraisal of the data in Moore's table 1 is that the larger dimensions are considerably exaggerated. Moore's graph (1985, fig. 4), in which basal diameter is plotted against column height and tephra finger jets are distinguished from uprush explosivity (his identifications), utilized incorrect data and the indicated positive exponential relationship is not justified. Also, the column heights, particularly those of tephra finger jets (e.g. Fig. la, d), are partly a function of when the photographs were taken, and thus for certain diameters the heights may be somewhat arbitrary minimum values.

Irrespective of the accuracy of the measurements, the diameters of the figured uprush columns are unlikely to relate to their vent and conduit dimensions in the manner indicated by Moore where (e.g. fig. 7d) the column and vent diameters are the same $(200 \mathrm{~m})$ and the diameter is little reduced at a considerable depth (about $175 \mathrm{~m}$ at the level of the former sea floor). The columns mainly show billowing lateral and upward expansion with convective ascent (e.g. Fig. 1b); at least one column (Fig. 1i) includes peripheral gravitational descent. The width of the convective part of an explosion column depends on many factors in addition to vent diameter. Most eruption columns are wider than their vents. None of the figured uprush columns shows clearly gas thrust at its base, yet it is the smallest diameter of a gas thrust region that might be closest to the true vent diameter. Mostly it is impossible to see anything of the base of an explosion column, because it is obscured by a collar of steam, fallout or jetted tephra, or the tuff cone (Fig. 1).

Even if it was possible to see the base of gas thrust in the column, the possibility that its diameter would be larger than the subsurface conduit diameter should be considered, because in the conduit the steam that drives the explosions is likely to be overpressured (Kieffer, 1984) with respect to atmospheric pressure. The heating of water and the explosive expansion of steam are continuous at shallow levels, and just below the level of emergence the jets and columns are liable to increase their diameter rapidly to become pressure-balanced on emergence (see Kieffer, 1984). In cases where a vent is in rock, such radial expansion produces a shallow crater by erosion, but in this case the upper part of the conduit is likely to be very unstable (see below) and the expansion probably has persistently to displace loose material. Thus the conduit within the volcanic pile probably is narrower than the diameter of the (obscured) base of the emergent jet or column.

The aims of the following discussion are to show that there is no reason to suppose that lavas formed a major portion of the volcanic pile, with explosive activity restricted to depths of less than about $40 \mathrm{~m}$, and that the postulated deep, open vent conditions are unlikely to have occurred. Also it is argued that there is no evidence for the downward quarrying invoked as a possible mechanism in diatreme formation.

Explosive activity must be suppressed by the hydrostatic pressure of overlying water, but Moore (1985, fig. 7a and conclusion 1) implies that suppression is so substantial that pillow lava and breccia were the main effusive products up to water depths as shallow as about $30-40 \mathrm{~m}$. However, there is (as far as I know) no direct evidence of there having been a substantial lava foundation beneath the tephra deposits of Surtsey. There was no strong magnetization detected there at the time when strong magnetization was recorded at nearby Surtla (Kjartansson, 1967; Sigurgeirsson, 1966).
Presumably a part of the lava pile remaining after the hypothetical 'quarrying' (see Moore, 1985, fig. 7d, e) should have been detectable then (before possible hydrothermal alteration). 'Lava' fragments in the Surtsey tephra deposits could well represent disruption of rock formed by cooling of magma within the pile during a period of repose, or isolated lava flow units that formed a minor component of the pile. Moore's model requires that the scattered lava fragments in the Surtsey tephra deposits are equivalent in volume to lavas quarried away. This equivalence, or lack of it, would be difficult to determine with certainty, because early products of the vent are inaccessible due to subsidence and burial, but lava clasts are not abundant in exposed sections (author's observations), and in Moore's crosssection through Surtsey (fig. 9) the lavas have been entirely quarried away.

Studies of the clastic deposits of Surtla (Kokelaar \& Durant, 1983) show that explosive volcanism certainly occurred at about $45 \mathrm{~m}$ below sea level and is also likely to have occurred at greater depths. Comparison of Surtla tephra with that of exposed subglacial volcanic sections indicates that in Surtla there probably is a considerable thickness of increasingly coarse material between $45 \mathrm{~m}$ and the top of the lava foundation (Kokelaar \& Durant, 1983). Analogous subglacial volcanoes in Iceland commonly show the transition to pillow lavas to occur at water depths between $100 \mathrm{~m}$ and $200 \mathrm{~m}$, though it can occur at shallower levels (Allen, 1980; Jones, 1970). Thus, substantial explosive activity could have occurred at hydrostatic pressures corresponding to depths greater than $\mathbf{4 0} \mathrm{m}$, and geophysical and indirect evidence indicate that the thick pile of pillow lavas of Moore's figure 7 probably did not form.

If it is believed that at water depths of $40 \mathrm{~m}$ ( 4 bars) explosive activity is suppressed so that lava is the major product, then the explosions at depths more than $200 \mathrm{~m}$ below sea level that are supposedly represented by large uprush columns can only have occurred at the bottom of a very deep, open hole where pressure was less than 4 bars. Moore appears to believe that this is the case and states that during continuous uprush: "The bottom of the crater must be relatively free of debris so that vesiculating, erupting fountains can spray lava into the bottom'; he also states that in a 'steady state hydromagmatic steam explosion' (continuous uprush) '... all water will be flashed to steam so that the vesiculating lava will erupt at a relatively dry, low-pressure crater bottom'. Thorarinsson's (1965) statement: 'While uprush lasted, the vent was dry to a great depth, and the risk of its vertical walls slumping was great when the pressure from the uprush diminished', apparently is regarded as corroborative.

However, it seems likely that the 'conduit' through the volcanic pile is nothing other than an ephemeral pathway, followed by fluid magma, expanding steam, and tephra, through a mobilized, perhaps partly fluidized, slurry of tephra, water and steam (Kokelaar, 1983). The variable location and direction of jets and columns show that the conduit is mobile and not rigid, and, although uprush columns commonly build vent-enclosing tuff cones or conelets, uprush clearly can occur when water has access to the conduit and so can exert a pressure there. One good photograph of continuous uprush (Thorarinsson et al. 1964, fig. 15) shows a column emerging from the centre of a small tuff cone. The column base, which appears to include a gas thrust region, is almost certainly less than $15 \mathrm{~m}$ in diameter. The small cone encloses the vent, but there is sea water at the foot of the cone on the outside. Film of the eruption at Jolnir (Knudsen, undated) shows that water floods freely 
through recently built tephra barriers that are several tens of metres wide, and the level of water standing in pools isolated from the open sea is known to respond to the fall and rise of tides (e.g. see Tryggvason, 1968). Thus it seems most likely that water had access to the 'conduit' beneath this uprush column. From the earlier discussions of column dimensions, and from numerous other photographs, it is clear that the vent diameter is most commonly smaller than the diameter of the crater area that is prone to flooding (bounded by the foot of the inner cone-slope), rarely if ever occupying the entire diameter in the manner indicated by Moore (1985, fig. 7d). Continuous uprush commonly occurs close to a body of water, and it is very unlikely in such a situation that Moore's deep 'relatively dry, low-pressure crater bottom' could exist. It is reasonable to say that uprush columns appear to contain less water per unit volume of tephra or magma than tephra finger jets, and so appear to be 'drier' (they are commonly incandescent), but it is not possible to see directly into a vent. The minimum pressure experienced anywhere in the conduit must be roughly equal to the hydrostatic pressure experienced in the adjacent water-saturated tephra. This is unlike the 'relatively open crater' invoked by Moore, which is more akin to some craters of subaerial volcanoes where atmospheric pressure can be attained beneath the crater rim because the crater walls are rigid.

In Moore's model 'The explosion column is maintained by delivery of about equal volumes of inward-seeping water and vesiculating lava to the base of the explosion crater'. It is very difficult to understand how this seepage could be delivered so locally and so far below the level of the original sea floor. Also, if after each major uprush eruption there was collapse into a hole of the dimensions suggested (e.g. Moore, 1985 , fig. 7d), then the surface manifestation would be far greater than the increments of subsidence that have been observed.

There is no unequivocal evidence of substantial quarrying into the volcano basement. Certainly there are fragments of the volcano's substrate in the Surtsey tephra deposits (Alexandersson, 1970), but these could simply be accidental xenoliths torn from the eruption fissure(s). It remains to be determined whether they are abundant enough to account for the very large volume inferred to have been quarried away (see Moore, 1985, fig. 9). Moore's proposal of downward quarrying is based on incorrect dimensions of the uprush columns and on unlikely vent conditions and processes. Consequently there is little reason to believe that some diatremes may result from the envisaged process.

The borehole into Surtsey was located $200 \mathrm{~m}$ east of the centre of the eastern crater (Surtur 1) and extended to $122 \mathrm{~m}$ below sea level (Moore, 1985). Before the eruption the depth to the sea floor was about $130 \mathrm{~m}$. Basaltic tuff recovered from the hole includes accretionary lapilli and vesicles characteristic of the subaerially deposited tephra of the Surtsey tuff cones, and Moore proposed that such material so far below sea level can only have got there by subsidence of subaerially deposited material. Normal faults concentric to the vents and cutting the tuff cones were active during the explosive volcanism; there is no dispute about the long-term substantial downward and inward collapse of subaerially deposited tephra. The model of explosive eruption processes diagrammatically illustrated by Kokelaar (1983, figs. 1, 2) requires that the vent-filling slurry is replenished by downward and inward movement of tephra towards the base of a funnel-shaped zone. Reworked tephra representing any remaining slurry is not likely to have been intersected by the borehole. Such an intersection would require the minimum diameter of the original crater floor to have been a little over $400 \mathrm{~m}$, which it never was. The collapse determined by Moore is consistent with Kokelaar's (1983) model.

\section{References}

Alexandersson, T. 1970. The sedimentary xenoliths from Surtsey: marine sediments lithified on the sea-floor. Surtsey Research Progress Report 7, 83-7.

ALLEN, C. C. 1980. Icelandic subglacial volcanism: thermal and physical studies. Journal of Geology 88, 108-17.

JONES, J. G. 1970. Intraglacial volcanoes of the Laugarvatn region, southwest Iceland, II. Journal of Geology 78, $127-40$.

KIEFFER, S. W. 1984. Factors governing the structure of volcanic jets. In Explosive Volcanism: Inception, Evolution and Hazards (ed. F. R. Boyd et al.), pp. 143-57. Washington D.C. National Academy Press.

KJARTANSSON, G. 1967. Volcanic forms at the sea bottom. In Iceland and mid-ocean ridges (ed. S. Bjornsson). Societas Scientiarum Islandica 38, 53-66.

KNUDSEN, O. undated. Sequel to Surtsey (sound-motion film). Vok Film, Reykjavik.

KoKelAAR, B. P. 1983. The mechanism of Surtseyan volcanism. Journal of the Geological Society of London 140, 939-44.

KokelaAR, B. P \& Durant, G. P. 1983. The submarine eruption and erosion of Surtla (Surtsey), Iceland. Journal of Volcanology and Geothermal Research 19, 239-46.

MoORE, J. G. 1985. Structure and eruptive mechanisms at Surtsey Volcano, Iceland. Geological Magazine 122, 649-61.

Sigurgeirsson, T. 1966. Geophysical measurements carried out during the year of 1965. Surtsey Research Progress Report 2, 181-91.

THORARINSSON, S. 1965. Some facts about the Surtsey eruption. Natturufraedingurinn 35, 153-81.

Thorarinsson, S. 1968. The last phases of the Surtsey eruption. Natturufraedingurinn 38, 113-35.

Thorarinsson S., Einarsson, T., Sigvaldason, G. \& Elisson, G. 1964. The submarine eruption off the Vestman Islands 1963-64. a preliminary report. Bulletin Volcanologique 27, 435-45.

Tryggvason, E. 1968. Result of precision levelling in Surtsey. Surtsey Research Progress Report 4, 149-58.

\section{PETER KOKELAAR}

Environmental Studies Department

University of Ulster

Newtownabbey, Co. Antrim

BT37 0QB

Northern Ireland, U.K.

9 June 1986 


\section{Reply}

SIRS - Explosive volcanic eruptions are important from both the standpoints of the products that they generate and the human risk that they impose, but the mechanics of eruption are poorly understood. The Surtsey eruptive episode was a remarkably well-documented historic hydromagmatic explosive event, yet the interpretation of these data is controversial, as indicated by the accompanying discussion by Peter Kokelaar; I welcome the opportunity to further discuss this problem. In any discussion of the Surtsey activity, it is obvious that Sigurdur Thorarinsson expended great energy and effort in documenting the eruption. He visited Surtsey more than 85 times, under conditions that were never easy and were commonly hazardous. The opportunities of being with him twice on Surtsey, as well as on nearby Heimaey during the 1974 eruption, were of great value to me and are experiences that I will never forget. My colleague Sveinn Jakobsson has guided me through many details of Surtsey geology and has suffered through endless discussion and argument. Haraldur R. Karlsson provided translations from Icelandic reports, and W. A. Duffield, G. W. Moore, and J. M. Thompson provided reviews of this reply. I appreciate this help.

In order to keep this reply manageable, the following five main items of Kokelaar's discussion will be addressed: (1) the measurements of the basal diameter of the eruption columns given by me may be excessively large; (2) even if the above measurements are reasonable, they need not define the shape or dimension of the conduit; (3) no evidence exists that a lava base ever underlay Surtsey; (4) during upward growth of the volcano from the ocean floor, the transition from effusive to explosive eruptions took place much deeper than $40 \mathrm{~m}$ depth; and (5) the deep open-vent conditions of my model, the local delivery of water to the base of the vent, and the possibility of diatreme formation by processes similar to the Surtsey continuous uprush style of explosion are unlikely.

\section{Item 1 (basal diameter of eruption columns)}

As indicated by Kokelaar, the photographic evidence presents problems because parts of the eruptive cloud are commonly obscured, the scale is uncertain and difficult to apply, and the part of the column that is rising may be confused with descending fallout. However, our primary data on the ephemeral explosion columns come from a voluminous photographic record. The readers can evaluate for themselves the nature of the data from the generally excellent drawings in Kokelaar's figure 1. Comments on five of the nine sketches follow; Kokelaar seems to find no major fault with my treatment of the other four.

\section{Figure 1(a)}

This sketch is based on a photograph taken 19 November 1963 , five days after the island first appeared the morning of 14 November. During early stages of activity, eruptions occurred almost continuously along a northeast-trending fissure, but rather soon they took place at distinctly separate vents along the fissure (Thorarinsson, 1964, p. 17) as shown in the photograph upon which this sketch is based. The first continuous uprush explosion specifically mentioned occurred on 20 November, the day after the photo was taken (Thorarinsson et al. 1964, p. 441). However, as early as 16 November, a vent at the extreme northeast end of the fissure exploded on an average of every fifth second (Thorarinsson et al. 1964, p. 438). This average of 12 explosions per minute is within the range of continuous uprush explosions (Moore, 1985 , p. 651).

\section{Figure $I(b)$}

This measurement is considered poor by Kokelaar because the diameter given is greater than the lowest visible part of the column. The base of the column is obscured on both sides by the crater wall, and clearly only the visible part of the column with nearly vertical margins could be measured. The interpretation then rests on the steepness of the slope of the inner crater wall, which I regard as temporarily steepened by the uprush.

\section{Figure I(e)}

The photograph on which this sketch is based was taken three hours after that of figure 1 (d), and graphically shows the change in activity and diameter of the eruption column when water is restricted from the vent (compare Kokelaar's fig. $1 \mathrm{~d}$ and $\mathrm{e}$ ). In fig. 1 (d) explosions occur in an inlet open to the sea; in fig. 1(e) the sea is dammed from the vent by a five-metre-high tephra wall (crater rim) built during the three-hour period. Water seepage through the dam is apparently limited to about the optimum rate to produce continuous explosions.

\section{Figure $1(f)$}

The use of island height as a scale is degraded when the camera in aircraft is directed downward, since the apparent island height is also partly the slope distance from shore to summit. However, the $200 \mathrm{~m}$ diameter of the small lake in this photo can be readily measured on maps and scaled vertical photos (Thorarinsson, 1965, p. 168; Jakobsson \& Moore, 1982, fig. 1 a, p. 78) and provides a more reliable scale than island height. Examination of the published photograph on which this sketch is based suggests to me that the diameter of the uprush column exceeds the $200 \mathrm{~m}$ lake diameter, contrary to Kokelaar's sketch.

Another lake (the northern lagoon) that appears in a previously unpublished photograph (Fig. 1) can also provide a reliable scale. This photograph of Surtsey, which is part of a large collection of photos given to me by Thorarinsson before his death, was taken by him on 1 April 1964, from an aircraft flying northeast of the island. The width of the northern lagoon (perpendicular to the southwestern line of sight) is close to $500 \mathrm{~m}$, as measured on the scaled vertical air photo of 11 April 1964 (Jakobsson and Moore, 1982, fig. $1 \mathrm{~b}$ ). Hence the visible base (or lowest visible part) of the continuous uprush explosion column appears to be about $300 \mathrm{~m}$ in diameter. Incidentally, this is the first photograph that shows this collapse-induced lagoon.

\section{Figure I(i)}

Kokalaar states that the proposed column diameter shown in this 22 June 1966, photograph of Jolnir is about three times wider than that of the crater as measured 2 and 30 days earlier. The Jolnir crater diameter apparently changed from $130-170 \mathrm{~m}$ on 24 May 1966, to $120-140 \mathrm{~m}$ on 20 June 1966 (Thorarinsson, 1968, p. 118, fig. 2), to about $220 \mathrm{~m}$ on 14 August 1966. Part of this enlargement could have resulted from the continuous uprush explosion of 22 June 1966, shown in Kokelaar's sketch 1(i), and hence the earlier crater diameters are not valid estimates of the diameter during the 


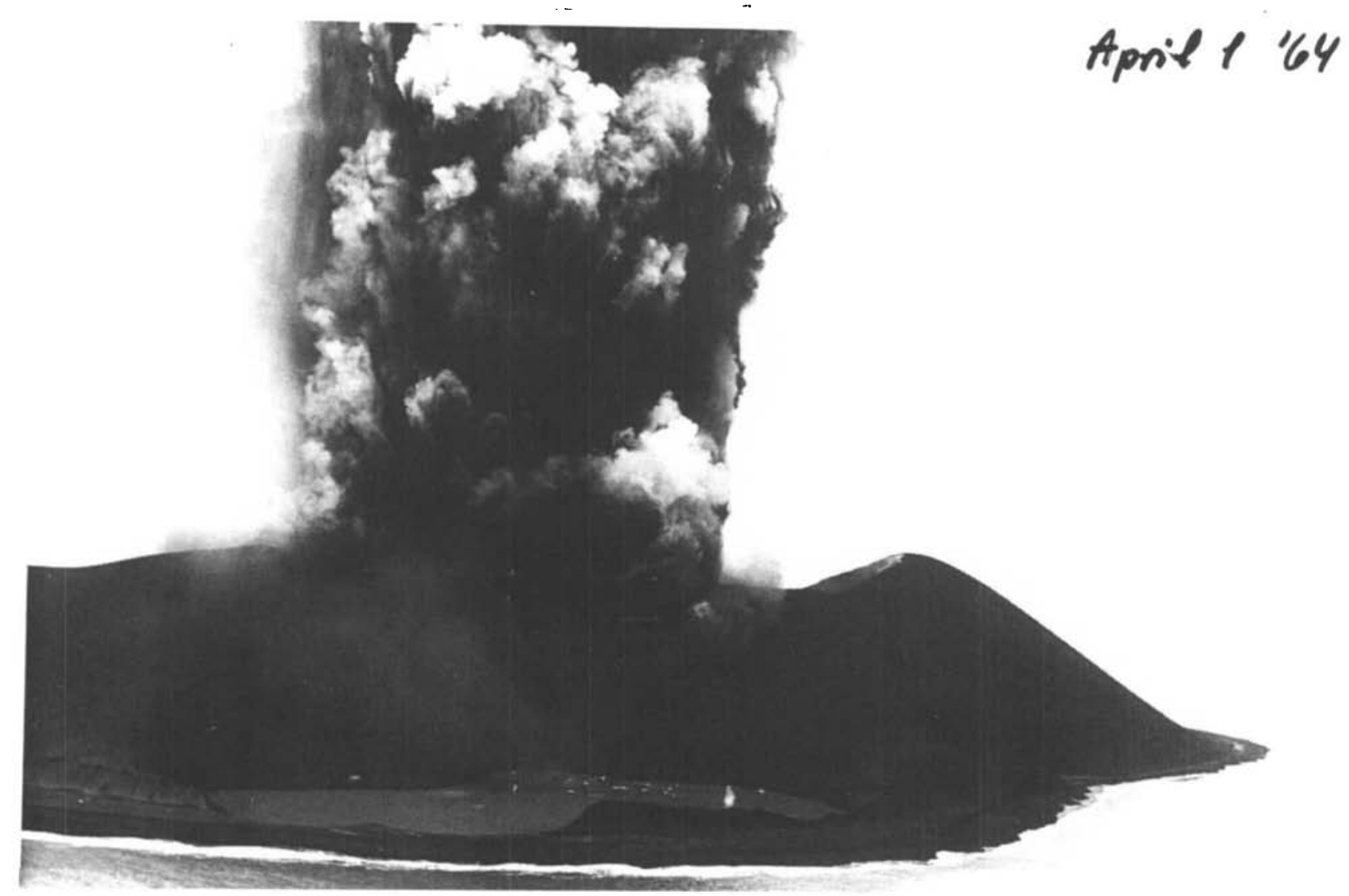

Figure 1. 1 April 1964 photograph of Surtsey taken from the northeast showing a massive eruption column rising from the western vent. This is the first photograph of the $500 \mathrm{~m}$ wide northern lagoon which formed between 19 March and 1 April 1964. Photograph by S. Thorarinsson.

activity of figure 1(i). The 14 August crater diameter was obtained by scaling on the photo of that date (Thorarinsson, 1968, plate II b) using an island length of $750 \mathrm{~m}$ as shown on the island outline of 20 June 1966 (Thorarinsson, 1968, p. 118, fig. 2b). Also, the extent of the downfalling ash curtain indicated on Kokelaar's sketch of figure 1 (i) is about twice as wide as that which can be supported by the photograph available to me.

\section{Item 2 (relative dimensions of eruption columns and conduit)}

Kokelaar states that the basal dimension of the eruption columns may not be a direct measure of the subsurface conduit dimensions. Certainly the conduit dimensions are speculative, but a few lines of evidence should be mentioned. Thorarinsson (1964, p. 18) states that 'when the explosions occurred some way down the vent the columns rose more or less vertically... when the explosions occurred nearer the top of the vent where its diameter was larger, the black tails formed curves so that the eruption column looked like an enormous cock's tail'. Hence this change in apparent trajectory from the outward-fanning cock's-tail explosions shown in Kokelaar's sketches $1(\mathrm{c}, \mathrm{d}, \mathrm{g}$, and $\mathrm{h}$ ) to the vertically directed trajectories of continuous uprush explosions in $1(a, b, e, f$, and $i)$, suggests that the continuous uprush column provides a gauge of conduit dimensions at some depth. Secondly, the fact that tephra apparently deposited subaerially is found to the bottom of the drillhole (122 $\mathrm{m}$ below sea level) requires that the intermittently open conduit extend to a greater depth. Only by explosive ejection of material from a depth greater than about $130 \mathrm{~m}$ below sea level can enough space be generated for this surfacedeposited tephra to slump to the drilled depth. Finally, evidence that supports a deep, large vent is the apparent disruption of a presumed original lava base beneath Surtsey, as discussed in the next item. This requires that the explosive vent and excavation extend some distance beneath the pre-Surtsey ocean floor depth of about $130 \mathrm{~m}$.

Kokelaar states that 'the columns mainly show billowing lateral and upward expansion with convective ascent...'. Certainly this is a different picture from that described by Thorarinsson et al. (1964, p. 440) who state:

But sometimes - especially when the vents have been quite surrounded by a tephra wall - the intermittent activity changes to a continuous uprush of tephra and steam which can go on uninterrupted for many hours (Figs. 9 and 17). The tephra column may then gradually reach a height of one $\mathrm{km}$, occasionally even two $\mathrm{km}$. This uprush is accompanied by a rumbling noise. At night the column glows up to a great height, and fiery bombs fall so frequently and in so great numbers that the entire outer slope of the crater wall on the leeside has sometimes been a glowing avalanche. The eruption column contains proportionally more tephra and less vapour than the column rising from the 'tephra finger' blasts, and lightnings are more frequent. This type of eruption has been by far the most effective in building up the crater walls and enlarging the island and they have caused the main tephra falls

The figures 9 and 17 referred to above have been used for 
Kokelaar's sketches 1 (b and e) respectively. Thorarinsson $(1964$, p. 18) states that "At the base of the eruption column the speed of the uprush was about 400 feet per second...' (i.e. about $120 \mathrm{~m} / \mathrm{s}$ ), and he compares this activity to that of the 6 April 1906 eruption of Vesuvius (Thorarinsson, 1965, p. 165).

\section{Item 3 (lava base under Surtsey)}

Kokelaar cites Allen (1980) and Jones (1970) as establishing that the depth of initiation of explosive volcanism in subglacial table mountains occurs between 100 and $200 \mathrm{~m}$. Allen (1980), who also cites the evidence of Jones (1970), points out the problems of determining the depth of the transition between the effusive phase and the explosive phase, and in his conclusions section states that the transition occurs '.. in most cases at a depth of 100-200 m'. But Allen (1980, p. 115) states that his estimates 'should thus be considered maximum applicable water depths.' Emphasis is mine.

\section{Item 4 (depth of transition from effusive to explosive eruption)}

Kokelaar states that there is no direct evidence of Surtsey ever having had a submarine lava foundation because in 1965 none of the strong magnetization such as that which apparently marks the lava base of nearby Surtla was present at Surtsey. He states that my section (Moore, 1985, fig. 7) shows a part of the lava pile remaining. Actually my figure 7 is not of Surtsey, but depicts the growth of a hypothetical marine volcano. My section of Surtsey (fig. 9) shows no remaining lava. The lack of a magnetic signature beneath Surtsey led me to assume that the lava pile that presumably originally formed beneath the east Surtsey vent was disrupted by explosion and collapse (before the magnetic survey of 1965) as indicated in my cross-section. It should be mentioned here that no submarine lava pile apparently was ever formed at the west Surtsey vent because it began erupting late and only in shallow water near the shoreline on the flank of the east Surtsey vent cone.

I do assume, however, that a submarine lava pile (presumably pillowed) originally formed at the east Surtsey vent as well as at the other vents of the Surtsey sequence that began eruption on the sea floor, which here is about $130 \mathrm{~m}$ deep. This assumption is based on the fact that all these vents seem to have remained nonexplosive until they grew up to very shallow depth, and when explosions were first noted, the top of the undersea volcano was commonly visible (data summarized in Moore, 1985, p. 650). Pillow-lava fragments have been reported on Surtsey (Lorenz, 1974) and dredged from the embryonic Jolnir when its summit was $74 \mathrm{~m}$ deep (Kjartansson, 1967, p. 59), and the strong magnetization of Surtla (Sigurgeirsson, 1966) indicates that it is underlain by lava.

\section{Item 5 (deep open-vent model and diatremes)}

Kokelaar questions the concept of the deep open-hole aspect of my model. It should be emphasized that this part of the explosion cycle is ephemeral and exists only during the period of continuous uprush explosions when rubble, water, and tephra are vigorously ejected from the vent, and sea water is restricted from entering it. This condition occurs only at optimum proportions of water to lava (Moore, 1985, fig. 8), when the mix is most explosive, that is, when the ratio of gas to solid plus liquid is greatest. Hence during 'open-hole conditions' the vent is filled with this expanding three-phase mixture, but the stage is set for collapse into the vent at the instant when the explosions wane. The longer the continuous uprush lasts (which may be several hours), the deeper the vent may quarry. This condition is not unlike that depicted in Kokelaar's unscaled model of continuous uprush explosions (1983, fig. 2), except for the facts that the sea does not have free passage into the vent (it is dammed by a tephra ridge or crater rim), the explosion column is much more gas-charged than his description and diagram suggest, and the diameter of the eruption column is far greater than $2 \frac{1}{2}$ times the width of the feeding dyke. Eye-witness accounts state that the continuous uprush occurred only when the crater rim grew to the point where free access to the sea was blocked, and when the crater rim was breached 'the sea could sometimes be seen to pour into the vent with gigantic breakers' (Thorarinsson, 1964, p. 17).

As mentioned by Kokelaar, the tephra is permeable, and the ocean tide rises and falls within interior bodies of water on the island. This fact is graphically shown in the dug pit and drillhole, where tides are commonly monitored. Ocean tides of several metres amplitude are attenuated to $2 \mathrm{~cm}$ amplitude and delayed about 6 hours in the dug pit $260 \mathrm{~m}$ distant from the closest shore on the north cape of the island (Moore, 1982, p. 98). The drillhole apparently transects more permeable tephra because the tidal flux in it is attenuated to about $2 \mathrm{~m}$ and is delayed 55 minutes relative to that in the open ocean (Moore, Jakobsson \& Norrman, 1986). Hence, on a scale of hours and parts of an hour, water moves readily through the tephra as emphasized by Kokelaar. However, on a scale of seconds and minutes, the tephra barrier could be expected to impede the flow of sea water into the vent.

During continuous uprush explosions, when the discrete explosions occur with a frequency exceeding 12 per minute, the water passing through the tephra into the vent is believed to be less than, or about equal to, that expelled. This water is flashed to steam as it mixes with magma. When such water is delivered at a volumetric rate about equal to that of lava fed into the conduit from below (estimated to average roughly $20 \mathrm{~m}^{3}$ per second), then the optimum conditions occur for continuous uprush explosions. If more water enters, the mix is quenched and explosions wane. If less water enters, insufficient steam is generated and explosions also wane. When explosions decrease, the continuous uprush cannot keep the conduit open, the walls collapse, water rushes in, and the process must begin again, as lava intrudes upward through the rubble-choked vent, and small intermittent vent-clearing explosions begin in shallow water. This same downward-quarrying process is an alternative model for explaining the formation of some diatremes, perhaps more reasonable than explosive action that bores up through thousands of metres of rock.

\section{Further references}

JaKoBSSON, S. \& MoORE, J. G. 1982. The Surtsey research drilling project of 1979. Surtsey Research Progress Report 9, 76-93.

LORENZ, V. 1974. Studies of the Surtsey tephra deposits. Surtsey Research Progress Report 7, 72-79. 
MoORE, J. G. 1982. Tidal and leveling measurements on Surtsey, July-August 1979. Surtsey Research Progress Report 9, 98-101.

MOORE, J. G., JAKobSSON, S. P. AND Norman, J. O. 1986. Investigation of Surtsey Volcano. Eos 67, 74.

Thorarinsson, S. 1964. Surtsey, the New Island in the North Atlantic. New York: Viking Press 47 pp.

JAMES G. MOORE

U.S. Geological Survey

Menlo Park

CA 94025

U.S.A.

23 July 1986 